\title{
URGENSI ROLE MODEL GURU DALAM PEMBENTUKAN SISWA BERKARAKTER DENGAN 5M
}

\author{
Imam Syahrobani \\ Email: imamsyahrobani@unisa.ac.id \\ Universitas Islam Al-Ihya Kuningan
}

\begin{abstract}
ABSTRAK
Model Peran (role model) merupakan faktor yang berpengaruh dalam menentukan seseorang berkarakter. Pentinganya role model bagi guru adalah sebuah keniscayaan jika ingin membentuk karakter siswa. Siswa harus bisa melihat dan merasakan role model dari guru untuk dijadikan acuan bagi mereka untuk membentuk karakter masing-masing. Tahapan untuk membentuk role model bagi guru adalah melalui tahapan 5M. Metode penulisan ini adalah kajian Pustaka. Dari hasil kajian Pustaka dapat diketahui bahwa tidak mungkin seorang guru bisa membentuk siswa berkarakter, sebelum guru itu sendiri harus mempunyai role model.
\end{abstract}

Keyword : Role Model, siswa karakter

\begin{abstract}
Role models (role models) are factors that influence in determining a person with character. The importance of role models for teachers is a necessity if you want to shape student character. Students must be able to see and feel the role model of the teacher to be used as a reference for them to shape their respective characters. The stages for forming a role model for teachers are through the $5 \mathrm{M}$ stages. This writing method is literature review. From the results of literature review it can be seen that it is impossible for a teacher to form student characters, before the teacher himself must have a role model.
\end{abstract}

Keyword: Role Model, student character 


\section{PENGANTAR}

Pendidikan merupakan hak bagi warna negara Indonesia. Tidak terkecuali. Karena Pendidikan merupakan sarana penting supaya Pendidikan berkualitas dan berkarakter. Pada pasal 3 UU no.20 tahun 2003 tentang Sistem Pendidikan Nasional menyebutkan bahwa Pendidikan nasional berfungsi mengembangkan kemampuan dan membentuk karakter serta peradaban bangsa yang bermartabat dalam rangka mencerdaskan kehidupan bangsa. Dalam membentuk Pendidikan karakter, kita membutuhkan role model/keteladanan yang baik supaya nilai yang diterima mudah diejawantahkan dalam kehidupan sehari-hari. Jika tidak ada role model dalam gambaran siswa, baik itu dari orang tua atau gurunya di Sekolah, sangat sulit menghasilkan output yang berkualitas dan sesuai dengan harapan tujuan Pendidikan nasional Bangsa Indonesia. Maka harus ada upaya dan Langkah-langkah sistematis dan terukur dalam menciptakan role model yang berkarakter, supaya hasilnya dirasakan oleh masyarakat, agama dan bangsa.

\section{PEMBAHASAN}

\section{Urgensi}

Urgensi menjadi kata yang sering kita dengar sehari-hari, baik dalam percakapan lisan maupun tulisan. Namun apa sebenarnya arti dari urgensi tersebut?

Menurut KBBI, urgensi adalah keharusan yang mendesak; hal yang sangat penting. Tidak hanya sekadar penting, tapi lebih dari makna penting itu sendiri. Misalkan urgensi Pendidikan tauhid bagi anak. Artinya Pendidikan tauhid itu sangat penting sekali bagi anak didik, sebab jika tidak belajar tauhid yang benar, maka perbuatan sehari-harinya khawatir terjerembab dalam dosa dan kejahatan. Contoh lain adalah urgensi budaya tata tertib lalu lintas di tol. Artinya budaya tata tertib itu mendesak dan sangat penting dilakukan agar mengurangi jumlah kecelakaan dijalan.

\section{Role Model}

Dalam teori kepemimpinan, arti kata sederhananya adalah teladan. Sedangkan menurut Wikipedia, role model adalah "person who serve as an example, whose behavior is emulated by others" atau seseorang yang memberikan teladan dan berperilaku yang bisa diikuti oleh orang lain.

\section{Karakter}

Menurut Hornby dan Parnwell (1972:49), pengertian karakter secara harafiah berarti, "kualitas mental atau moral, kekuatan moral, nama atau reputasi. Sedangkan menurut M. Furqon Hidayatullah (2010:13), karakter adalah kualitas atau kekuatan mental atau moral, akhlak atau budi pekerti individu yang merupakan kepribadian khusus yang menjadi pendorong atau penggerak, serta yang membedakan dengan individu lain. Seseorang dapat dikatakan berkarakter ketika orang tersebut telah berhasil menyerap nilai dan keyakinan yang dikehendaki masyarakat serta digunakan sebagai kekuatan moral dalam hidupnya. Menurut kamus bahasa Indonesia Purwadarminto, karakter diartikan sebuah tabiat, watak, sifat-sifat kejiwaan, akhlak atau budi pekerti yang membedakan seseorang dari orang lain. Karakter merupakan nilai-nilai perilaku manusia yang 
berhubungan dengan Tuhan Yang Maha Esa, diri sendiri, sesama manusia, lingkungan dan kebangsaan yang terwujud dalam pikiran, sikap, perasaan, perkataan, dan perbuatan berdasarkan norma-norma agama, hukum, tata krama, budaya dan adat istiadat. Karakter merupakan sifat kejiwaan, akhlak atau budi pekerti yang menjadi ciri khas seseorang atau sekelompok orang. Jadi, karakter adalah hasil dari proses Pendidikan yang bertujuan menciptakan nilai-nilai luhur dan berbudi pekerti.

\section{Pembentukan siswa berkarakter}

Adalah upaya untuk membentuk kepribadian siswa mempunyai karakter yang kuat, yang siap bersaing di kehidupan modern ini. Sebab, orang yang mempunyai tingkat IQ(Intelegensi Quotient) tinggi akan kalah bersaing dengan orang yang mempunyai tingkat EQ (Emosional Quotient) tinggi. Begitupun juga orang yang mempunyai tingkat EQ tinggi, akan kalah dengan orang yang mempunyai tingkat SQ (Spiritual Quotient) tinggi.

Namun untuk mengaplikasikannya, membutuhkan proses yang tidak sebentar. Butuh kesabaran dan keuletan yang kuat dalam proses tersebut. Dan salah satu indikator sukses siswa berkarakter adalah dengan adanya Role Model dari guru yang bisa menggambarkan Nilai/Value dari ilmu yang diterima oleh peserta didik.

Karakter menjadi hal yang terpenting dalam kehidupan seseorang, karena bisa mempengaruhi kesukseskan dimasa depan. Jika kita ingin melihat role mode sesungguhnya adalah ada pada dalam diri Muhammad Rasulullah SAW. Beliau jelas-jelas adalah role model dalam segala hal. Allah SWT berfirman yang artinya, " Sungguh telah ada dalam diri Rasulullah, suri teladan yang baik." (QS Al-Ahzab : 21).

Rasulullah disebutkan sebagai AL-Quran berjalan. Karena beliau lah kesempurnaan Akhlak, baik dari segi apapun. Perkataan dan perbuatan beliau sellau dijadikan rujukan bagi siapapun, walaupun bebeda kenyakinan. Beliau mempunyai budi pekerti yang agung sampai-sampai Michael H. Hart dalam bukunya 100 orang yang paling berpengaruh di Dunia salah satunya adalah menempatkan Muhammad SAW dalam posisi nomor 1 diantara tokoh-tokoh lain. Walaupun penulisnya sendiri adalah bukan agama Islam. Ini juga dianggap salah satu bukti betapa Rasulullah SAW adalah suri tauladan yang baik.

Jika ingin mempunyai siswa berkarakter, maka hendaklah gurunya harus bisa menjadi role model untuk dijadikan acuan siswa. Sangat mustahil jika guru itu sendiri melalaikan hal ini.

Diantara upaya untuk membentuk role model bagi para guru bisa disingkat melakukan Tahapan 5M. Tahapan ini dianggap sangat efektif untuk menciptakan role model.

Pertama, menyadari pentingnya berkarakter.

Menyadari menjadi guru berkarakter adalah menjadi manusia seutuhnya. Tanpa kita menyadari bahwa hal itu sangat urgen dalam kehidupan kita, maka kita tidak akan pernah berusaha untuk menjadi guru berkarter. Karakter baik akan 
membantu kehidupan manusia, mempunyai karakter ramah dan sopan akan bisa menciptakan situasi yang terkendali jika ada konflik baik itu konflik kecil maupun besar. Karakter peduli dan menolong akan memperbesar kebahagian dari sisi pandang lain, karena semakin kita peduli dan menolong orang, maka semakin besar pula hormone kebahagiaan. Karena dalam agama maupun budaya secara fitrah, peduli dan menolong orang adalah sebuah kebajikan yang sangat besar. Apalagi disaat zaman sekarang yang egois dan tidak peduli dengan orang lain. Mempunya karakter memahami dan tenggang rasa akan menjadikan kita sebagai makhluk sosial akan kuat dan kokoh, karen saling memahami. Itulah contoh-contoh betapa pentingnya karakter dalam kehidupan kita. Bagaimana jadinya jika kita tidak mempunya karakter-karakter diatas? Sudah pasti akan menimbulkan perpecahan, permusuhan, saling balas dendam, saling mengejak, dll.

\section{Kedua, mengembangkan karakter dalam dirinya.}

Setelah kita memahami betapa pentingnya karakter bagi guru dan bagi kita semua, saatnya melangkah ke tahap kedua, yaitu mengembangkan karaktrer dalam dirinya.

Harus sadar sepenuhnya bahwa karakter itu suatu hal yang tidak bisa ada secara tiba-tiba. Berawal dari hal-hal kecil yang terkadang terasa tidak ada manfaatnya, tapi jika terus menerus berpacu dengan waktu, ada sesuatu hal tersebut akan besar dan bisa membuat sejarah yang besar bagi kehidupan kita. Diantara buku-buku tentang hal ini banyak, salah satunya adalah karya James Clear berjudul atomic habits. Penulis menjelaskan dengan gamblang tentang pembentukan karakter -yang Bahasa penulis disebut identitas- dari hal-hal yang kecil dan terasa remeh, namun membawa perubahan yang sangat besar. Pilihlah karakter-karakter yang utama yang akan dikembangkan pertama kali. Pertajam karakter-karakter itu sehingga Ketika sudah cukup, bisa mengambil penajaman karakter-karakter yang lain. Berfokuslah kepada system pengembangannnya, bukan kepada hasil akhirnya. Sebab banyak orang yang berhenti mengejar hasil, dikarenakan merasa tidak kuat untuk mencapainya.

\section{Ketiga, mengamalkan secara konsisten karakter yang baik tersebut dalam keseharian.}

Konsisten adalah kunci dalam proses. Konsisten seperti bahan bakar bensin kendaraan. Sebagai apapaun kendaraanya, tapi tidak bisa jalan karena tidak ada bahan bakar bensinnya. Konsisten dalam membentuk karakter itu harus terus dilakukan tiap hari dan siapkan evaluasi setiap akan tidur. Berkonsisten itu sangat penting, karena kita akan melawan pikiran kita. Dalam buku The 5 Second, Mel Robbins mengatakan bahwa pikiran itu tidak suka kepada perjuangan dan kerja keras, ia hanya suka kepada santai, bermalas-malasan; maka terkadang Ketika akan melakukan perbuatan baik, pikiran akan membisikan sesuatu yang intinya tidak usah melakukan itu. Karena pikiran menjadi musuh bagi perjuangan untuk konsisten, maka ada upaya untuk menekan itu. Salah satunya adalah Reward dan Punishment. Dua hal ini adalah sebagai respon atau perbuatan kita. Reward sebagai apresiasi/penghargaan atas capaian hari ini. Jika ternyata tidak melakukan perbuatan yang ditetapkan, maka kita perlu melakukan punishment atau hukuman 
untuk diri karena tidak mengerjakan hal itu. Ini betujuan agar kita perpikir kembali betapa alasan-alasan itu hanyalah nafsu dan rasa malas saja.

\section{Langkah yang keempat ialah memberikan contoh (teladan) kepada} orang lain.

Karakter yang telah terbentuk tidak mempunyai nilai apapun sebelum karakter itu kemudian menjadi teladan bagi orang lain. Maka, berikanlah teladan/contoh baik dalam suatu hal, dan lakukan itu terus menerus. Jangan menunggu pujian dari orang lain. Tugas kita adalah memberikan teladan, bukan menunggu pujian orang lain. Konsisten dalam hal itu dan nanti akan terlihat efek positifnya.

\section{Langkah yang kelima adalah mengajak masyarakat untuk menyadari dan mengembangkan karakter yang baik.}

Setelah kita berikan teladan/contoh terus menerus, saatnya untuk mengajak masyarakat dengan pelan-pelan dan lembut untuk mengembangkan karakter-karakter tersebut. Ajarkan pula Langkah demi Langkah 5M dengan pasif dan kosisten. InsyaAllah $5 \mathrm{M}$ itu akan meningkatkan dan menciptakan karakter-karakter bagi siapapun terutama bagi seorang guru sehingga siswa bisa melihat guru itu sebagai role model pengembangan sehingga bisa mengarahkan dan menciptakan siswa berkarakter.

\section{KESIMPULAN}

DIkarenakan guru sebagai ujung tombak Pendidikan, maka kualitas guru harus dikembangkan. Alih-alih ingin membentuk siswa berkarakter, maka ciptakanlah karakter guru terlebih dahulu agar bisa menjadi role model bagi siswa. Mempersiapkan karakter-karakter itu tidak mudah membalikan setengah tangan, tapi sangat bisa diciptakan melalui metode 5M. 


\section{REFERENSI}

(n.d.). https://kbbi.web.id/urgensi

Widiastuti, H. (2012). Peran Guru Dalam Membentuk Siswa Berkarakter.

Riyanto, E. IMPLEMENTASI KARAKTER BUILDING DI ERA MILENIAL PADA PESERTA DIDIK. IMPLEMENTASI PENDIDIKAN AGAMA DAN PENDIDIKAN KARAKTER, 1.

Hart, M. H. (2009). 100 Orang Paling Berpengaruh di Dinia Sepanjang Sejaran. PT Mizan Publika.

Pasiak, T. (2008). Revolusi Iq/eq/sq. PT Mizan Publika.

Huda, S. N., \& Afrina, F. (2020). Rasulullaah Sebagai Role Model Bagi Pendidik (Kajian Terhadap Al-Qur'an Surah Al-Ahzab Ayat 21). Fitrah: Journal of Islamic Education, 1(1), 72-88.

Dalyono, B., \& Lestariningsih, E. D. (2016). Implementasi penguatan pendidikan karakter di sekolah. Bangun Rekaprima: Majalah Ilmiah Pengembangan Rekayasa, Sosial dan Humaniora, 3(2, Oktober), 33-42.

Gunawan, H. (2012). Pendidikan karakter. Bandung: Alfabeta, 2.

Wakhudin, W. (2018). Menjadi Guru Berkarakter: Meneladani Kepemimpinan Drs. H. Ajat Sudrajat, MM Pd. dalam Membangun Sekolah Berkualitas. MIMBAR PENDIDIKAN, 3(2), 169-188.

Setiawan, D., \& Sitorus, J. (2017). Urgensi tuntutan profesionalisme dan harapan menjadi guru berkarakter (Studi kasus: Sekolah dasar dan sekolah menengah pertama di Kabupaten Batubara). Cakrawala Pendidikan, (1), 122-129.

Kosim, M. (2012). Urgensi pendidikan karakter. KARSA: Journal of Social and Islamic Culture, 19(1), 84-92.

Clear, J. (2018). Atomic Habits: The life-changing million copy bestseller. Random House.

Robbins, M. (2017). The 5 second rule: Transform your life, work, and confidence with everyday courage. Simon and Schuster. 